\title{
СРПСКИ ЈЕЗИК У СВЕТЛУ ТЕОЛИНГВИСТИЧКИХ ИСТРАЖИВАњА**
}

\begin{abstract}
У раду се даје преглед основних праваца истраживања у српској теолингвистици (на подручју опште лингвистике, србистике и славистике и страних филологија), са приказом најважнијих резултата постигнутих на фундаменталним и апликативним подручјима проучавања језика сакрума (из синхронијске перспективе) који се излажу у монографским публикацијама, радовима објављеним у тематским зборницима, зборницима са научних скупова и научним часописима у током последње деценије. Разматрају се и перспективе даљег развоја ове дисциплине у србистици и српској лингвистичкој русистици.

Кључне речи: теорија и методологија лингвистике, српска лингвистика, теолингвистика, србистика, славистика, русистика, монолингвална и конфронтациона истраживања српског језика.
\end{abstract}

0.1. Једна од новијих истраживачких парадигми у славистици јесте теолингвистички приступ. Предмет теолингвистичких истраживања, најјезгровитије речено, представља језик сакралног и сакрално у језику, односно „Пројаве религије које су нашле свој израз и одраз у језику, али и језик као форма религије, као начин манифестовања, конзервације и трансмисије религијских садржаја”. Објекти истраживања теолингвистике јесу: сакрални језик (и сакрални језици), појаве у развоју лингвистике условљене конфесионалним факторима, теорије о пореклу језика (пре свега теорија о божанској суштини и пореклу језика), питања функционисања језика у домену религијског, као и све појаве које су везане за сакралну сферу, а које су нашле свој одраз и израз у језику. Циљ теолингвистике јесте изучавање свега што је

\footnotetext{
*kkoncar@mts.rs

** Рад је израђен у оквиру пројекта Српска теологија у XXI веку: фундаменталне претпоставке теолошких дисциилина у европском контексту - историјска и савремена перспектива, који финансијски подржава Министарство просвете, науке и технолошког развоја Републике Србије (број пројекта: 179078 ОИ, руководилац пројекта проф. др Богољуб Шијаковић, носилац пројекта Православни богословски факултет, Универзитет у Београду).
} 
везано за сакралну сферу, а што је нашло одраза у језику и што је фиксирано самим језичким средствима, као и примена резултата добијених фундаменталним истраживањима (детаљније в. Кончаревић 2015: 11-138; Гадомски 2017: 19-32).

0.2. У неколико претходних публикација покушали смо да сагледамо историјски развој теолингвистике у европским оквирима, а посебно у словенским земљама у којима је ова наука до сада постигла најзапаженије резултате - Русији, Украјини и Пољској (исп. Кончаревић 2015: 11-34; Гадомски 2017: 55-114; осврт на развој теолингвистике у српским замљама понудили смо у: Кончаревић/Петровић 2016, а библиографски преглед студија, расправа и дела из словенске теолингвистике класификован по тематском принципу понудили смо у: Кончаревић 2015: 335-362). Циљ овога рада јесте приказивање стања у српској теолингвистици у последњој деценији, доминантних сфера истраживања (из синхронијске перспективе) и најеминентнијих истраживача. Резултате постигнуте у времену њеног конституисања, на основу библиографске грађе за период од 2000. до 2013. године која је обухватила монографије, студије и чланке објављиване у периодици, тематским зборницима и зборницима са научних скупова на српском језичком подручју, објавили смо у: Кончаревић/Петровић 2016) ${ }^{1}$, тако да прилог који сада нудимо пажњи научне јавности представља преглед нове етапе у развоју српске теолингвистике, која кореспондира са минулом деценијом. Грађа за рад ексцерпирана је из примарних и секундарних извора, при чему су консултована не само филолошка и теолошка него и издања из других друштвено-хуманистичких наука. Радове српских лингвиста објављиване у иностранству узимамо у обзир на основу претраживања персоналних библиографија. Радови страних лингвиста објављени на страницама српских гласила, с обзиром на интенцију аутора да прикажу конституисање српске теолингвистике, у овом библиографском приказу такође су изузети.

1. Теолингвистика се, како ћемо показати у излагању које следи, на српском језичком подручју развија у различитим правцима, обухватајући скоро све области истраживања које су уочене у другим словенским земљама). Појавило се неколико монографских публикација и докторских дисертација које означавају крај конститутивне и почетак развијене фазе теолингвистичких истраживања српског језика у монолингвалној и конфронтационој перспективи. Ова етапа отпочела је издавањем двају зборника теолингвистичких радова - једног у издању Православног богословског факултета (Гадомски/Кончаревић 2012) и другог у издању САНУ (Грковић Мејџор/Кончаревић 2013).

2.0. Од монографских публикација поменућемо књиге Ксеније Кончаревић, Иване Кнежевић и Наташе Вуловић (која је уједно допуњена и редиго-

\footnotetext{
${ }^{1}$ Интегрални увид у теолингвистичку продукцију у Србији, Црној Гори и Републици Српској (укључујући и радове страних аутора који су објављивали у домаћим часописима и зборницима) за период од 2000. до 2013. пружа библиографија коју је израдио Срђан Петровић, а која обухвата преко 350 јединица (Петровић 2015).
} 
вана верзија њене докторске дисертације), а од докторских теза оне чији су аутори Ружица Бајић и Ивана Кнежевић.

2.1. Хронолошки посматрано, прва ауторска књига из области теолингвистике јесте Теолошки дискурс енглеског и српског језика Иване Кнежевић (Кнежевић 2010). Дело се бави проблематиком лингвистичких (лексичко-семантичких, терминолошких), стилистичких и лингвокултуролошких аспеката превођења теолошке и литературе из области православне духовности са енглеског на српски језик и обрнуто, при чему преводилачке поступке, домете и промашаје документује богатом ексцерпираном грађом.

2.2. У књизи Сакрална комуникација: норме, традииије, средства (Кончаревић 2013) на материјалу руског и српског језика расветљавамо неке битне аспекте сакралне комуникације и мисије Цркве. У првом поглављу пажња је усмерена на феномен комуникационог понашања чланова Цркве, његових норми, традиција, вербалних и невербалних средстава, стандардних комуникативних сфера и ситуација у сфери сакралног, при чему се, на синхронијском и дијахронијском материјалу српског и руског језика, представљају три модела описа и анализе сакралне комуникационе културе - ситуациони, аспекатски и параметарски. Друго поглавље разматра сакралне језике ареала Slavia Orthodoxa у прошлости и данас, пре свега са социолингвистичког и лингвокултуролошког аспекта, али и из перспективе језичке политике и језичког планирања у окриљу Цркве. Завршно поглавље организовано је око феномена религиолекта - посебног језичког израза унутар заједнице Цркве којим се њени чланови служе у сфери друштвене свакодневице, културној, образовној, професионалној и сфери масмедија (на хришћанским радиостаницама, у штампи, на интернет презентацијама), и којим се одељују од оних који говоре истим језиком, али нису чланови те заједнице или нису довољно пришли Цркви, као и око односа између општејезичке норме и сакралног стандарда.

2.3. Монографија Поглед у теолингвистику (Кончаревић 2015) представља логичан и очекиван наставак наших теолингвистичких истраживања из претходног периода. После претходних истраживања у тој области, која су била разноврсна и проблемски, и концепцијски, и жанровски, у овој књизи уводимо читаоце у нове кругове теолингвистичке проблематике и отварамо нове видике у тој области, постављајући нова питања и нудећи нове одговоре. Књига има тринаест глава структурираних у три целине, односно три подручја испитивања: 1. теоријско-методолошки аспекти теолингвистичких истраживања, 2. лексикологија, стилистика сакрума, сакрална генологија, сакрални дискурс и 3. теолингвистика у примени (лексикографија, традуктологија). Како је ова књига наишла на добар одзив у научној јавности, на њој се нећемо дуже задржавати. Рећи ћемо да је она, као пионирска систематизација теолингвистике на српском језичком подручју, нашла примену на докторским студијама Филолошког факултета Универзитета у Београду, где је од 2015. акредитован предмет Теолингвистичка проучавања словенских језика.

2.4. Најзад, својеврсну енциклопедију теолингвистике представља наша књига Језик и религија: Појмовник теолингвистике (Кончаревић 2017), са 
преко 110 одредница. Ово дело представља покушај да се на једном месту нађе одређен, репрезентативан број базичних термина и терминолошких синтагми из теолингвистике. Пошто је у питању интердисциплинарна област, овде су у одређеној мери репрезентоване и јединице из теолингвистици контактних и комплементарних области теологије, религиологије и лингвистике битних за њено конституисање и разраду. Посебну пажњу посветили смо сакралним језицима, најзначајнијим сакралним споменицима у којима су сачуване културне и цивилизацијске вредности традиционалних религија, као и појмовима везаним за ширење духовних спознаја у тим религијама, а посебно за мисију и комуникацију православне Цркве. Све одреднице везане за теолингвистичке јединице језика објашњене су на материјалу српског језика.

2.5. За разлику од претходних монографија, дело Наташе Вуловић Српска фразеологија и религија. Лингвокулуролошка истраживаға (Вуловић 2015) превасходно је монолингвалног карактера. Предмет истраживања Наташе Вуловић у овој монографији, насталој на темељу њене докторске дисертације, јесу фразеолошке јединице с религијским компонентама у српском језику, које до сада у србистици углавном нису биле описане као посебан лексичко-фразеолошки слој, нити детаљније подвргнуте анализи. Анализа структурно-семантичког састава анализираних фразеолошких јединица заснована је на дескриптивно-аналитичком приступу, док је семантичка анализа укључила методе когнитивне лингвистике (фразеолошка компонентна анализа, као и концептуална анализа у оквиру лингвокултуролошких разматрања). Са лингвокултуролошког аспекта корпус је посматран кроз концепте опозиција, битне за културолошку анализу лингвистичким средствима. Такође, осим метода теоријске анализе интердисциплинарних резултата из литературе, коришћена је и статистичка метода описа и приказивања појединих резултата.

Истраживање је вршено са становишта синхронијске фразеологије, уз примену резултата дијахронијских истраживања у лексикологији и фразеологији (историјско-етимолошких) при анализи појединих примера (на местима где прототипска ситуација или кључна, културолошки маркирана лексема фразеологизма, изискују увид у историју језика и културе). С обзиром на интердисциплинарни карактер фразеологије, у истраживање су систематски инкорпориране и чињенице из етнолингвистике, културологије, историје религије, митологије, библистике, литургике, хеортологије, историје хришћанства и националне историје Срба и других контактних и комплементарних дициплина. Посебну вредност овој монографији придаје њено лингвокултуролошко утемељење, које логично проистиче из културних конотација паганско-митолошке и јудеохришћанске провенијенције које су наталожене у фразеолошким јединицама, а уграђене су у основни фонд нашег књижевног језика, у етичке принципе, па и естетска мерила српског народа. Српска фразеологија и религија јесте дело које доприноси и реконструисању карактерологије Срба и Јужних Словена, менталитета говорника српског језика, њихових традиционалних вредносних ставова и социјализа- 
цијских образаца преношених са колена на колено, што представља корисну грађу за етнолошка, антрополошка, етнопсихолошка, социолошка и културолошка проучавања.

2.7. Од докторских дисертација које су остале у рукопису поменућемо две - Научни стил енглеског и српског језика у области теологије (Кнежевић 2011) чији је аутор англиста Ивана Кнежевић и Лексика из сфере православне духовности у српском језику и њена лексикографска обрада Ружице Бајић (Бајић 2013).

2.7.1. Предмет истраживања Ружице Бајић јесу лексичке јединице савременог српског језика обједињене у семантичком смислу појмом $n p a-$ вославна духовност, то јест тематска група лексема из сфере православне духовности. Конкретно: опис овог слоја лексике у савременом српском језику, његова подела на подгрупе, а затим, у извесној мери, и семантичка, творбена и етимолошка анализа једне од тематских подгрупа („Црква”). Овај део лексике посматра се у истраживању и лексикографски: даје се предлог израде специјалног речника лексике из сфере православне духовности, као и предлог неких измена у лексикографској обради ових лексичких јединица у српској описној лексикографији, првенствено у Речнику српскохрватског књижевног и народног језика Српске академије наука и уметности (РСАНУ). У састав доктората ушао је и Тематски тезаурус лексике православне духовности (ТТЛПД) са око 15.000 лексема, што битно појачава његову апликативну димензију.

2.7.2. Ивана Кнежевић позабавила се стилом теологије као науке, његовим екстралингвистичким одликама и изражајним средствима у енглеском и српском језику, карактеристикама на лексичком, морфолошком и синтаксичком плану, подстиловима и жанровима, као и проблемима превођења теолошких текстова са енглеског језика на српски и обрнуто. Како ауторка наводи, стил теолошких наука, уопште узев, показује низ додирних, али и мноштво диференцијалних црта у односу на стил других научних области. Специфична екстра- и интралингвистичка обележја теолошког научног стила условљена су специфичношћу методологије богословља и карактера богословског познања у односу на логичко-епистемолошку природу знања у другим областима науке. Наиме, православна теологија поистовећује се са Православљем уопште, са целокупним животом (догматима, литургијом, подвигом) Цркве, са свим оним што обухвата православно духовно Предање и наслеђе. Стога је на плану свога језичког израза теологија знатно отворенија, приступачнија поимању далеко ширег круга реципијената него што је то случај са другим научним дисциплинама. Управо због чињенице да је информација која се пласира намењена широком кругу прималаца, стил теологије презентира садржај у доступној, разумљивој форми, која, наравно, ниуколико не сме да иде науштрб научности излагања. Поред тога, примаоца је веома често неопходно уверити у истинитост и важност поруке, односно на њега утицати и интелектуално, и емоционално, и волитивно, па се због тога у теолошком стилу неретко примењују и таква емоционално-експресивна средства деловања као што су тропи и стилске фигуре. Такав израз није 
монолитан нити се његов аутор може свести на једну димензију: теолог је пре свега истраживач, али и проповедник, и уметник речи.

3.1. Од истраживача који су објавили највећи број теолингвистичких иновативних радова у периодици, а у којима се српски језик посматра монолингвално или конфронтационо, поменућемо Ружицу Левушкину, Ивану Кнежевић, Зорана Ранковића и Срђана Петровића. Због ограниченог простора анализираћемо њихове најзначајније радове.

3.2. Ружица Левушкина веома је продуктиван аутор са више од тридесет радова објављених после докторирања. Из угла терминологије, лексикологије, лексикографије и терминографије језички материјал анализиран је у више њених прилога. У раду (Левушкина 2017а) говори се о лексици из општег лексичког фонда која функционише као терминолошка. Најпре се наводе битне опште особине лексике ове области. Лексеме које су материјал за истраживање класификоване су у четири групе и наведени су карактеристични примери за сваку од ових група. Показало се да су неке лексеме изразито вишезначне, има и примера синонимије и варијантности, а кад је у питању сфера тријадологије - експлицитно се објашњава семантика појединих лексема из општег лексичког фонда које функционишу као термини у њој. Неке лексеме су термини само у одређеним морфолошким облицима: множини и одређеном придевском виду. Највећи део њих су у саставу терминолошких и(ли) ономастичких синтагми. У раду (Левушкина/Јовановић 2018) изложен је преглед постојећих терминолошких речника у српској средини. Такође, дат је и општи поглед на стање терминологије као дисциплине (терминословља) у србистици. Предложени су и неки конкретни кораци који би се могли предузети на пољу развоја дате дисциплине. У раду (Левушкина 2017б) терминологија савременог српског језика подељена је на терминосистеме и подсистеме, од којих су семантички најважнији у раду описани детаљније. На крају је наведено и која су истраживања из ове области потребна да би се постигло да терминологија сфере православне духовности буде у потпуности инвентаризована и описана са разних лингвистичких аспеката, чиме би, истовремено, и српска (тео)лингвистика, а и терминологија као засебна дисциплина, биле проширене и обогаћене новим достигнућима. У раду (Левушкина 2016) описан је дескриптивни тематски тезаурус лексике из сфере православне духовности (ТТЛПД) и предложена је његова израда. Образложен је циљ постојања овог речника, његова намена, перспектива посматрања одредница у њему, елементи и потреба за постојањем оваквог речника у српској културној и образовној средини. Описан је и садржај његове макроструктуре и изглед микроструктуре и предложена су још нека техничка решења речничког чланка. Лексика православне духовности у српском и руском језику посматрана је лингвокултуролошки у раду (Левушкина 2019), где је наведена синхронијска упоредна анализа лексике православне културе двају језика на материјалу од приближно 200 парова лексичких јединица. Искоришћена је концепција и терминологија В. В. Дубичинског, на основу које је материјал представљен кроз потпуне и непотпуне лексичке паралеле. Анализом једног дела материјала Ружица Левушкина је дошла до закључка 
да он може бити анализиран такође у виду посебне врсте лексичких паралела, за које је предложила термин асиметричне лексичко-културне паралеле.

3.3. Ивана Кнежевић и Зоран Ранковић баве се елементима сакралног функционално-стилског комплекса у српском и енглеском језику: административним стилом (Кнежевић/Ранковић 2016а), уџбеничког и академског подстила научног теолошког стила (Кнежевић/Ранковић 2014, Кнежевић/Ранковић 2016б), фокусирајући се углавном на одређене лексичке слојеве и проблеме њиховог превођења.

3.4. Срђан Петровић два рада темељи на асоцијативним речницима руског и српског језика, идентификујући најзначајније конституенте стереотипа вере и духовности, који се доста разликују у анализираним језицима (Петровић 2015б, Петровић 2015в). У раду (Петровић 2016) сагледавају се јединице лексичког система руског и српског језика које припадају широј лексичко-семантичкој групи монашка духовност. Грађу сачињавају именичке лексеме са архисемом монах. Применом компоненцијалне анализе и конфронтативног метода сагледавају се истоветности, сличности и разлике у погледу лексичко-семантичких одлика дате групе лексема. Предлаже се модел њихове могуће класификације на примеру двају анализираних словенских језика и износе општа запажања у вези са обележјима издвојених (под)група именица из лексичко-семантичког угла. Предмет рада (Петровић 2017) чине јединице лексичког система руског и српског језика, а конкретно именичке лексеме са архисемом монах. Сагледава се ниво семне структуре лексема, уз идвајање диференцијалних и интегралних сема које ће послужити за даљу систематизацију и анализу ексцерпиране грађе. На тај начин сагледавају се манифестоване истоветности, сличности и разлике, као и утврђују релевантна лексичко-семантичка обележја издвојене групе именица с циљем њихове што свеобухватније дескрипције у руском језику у поређењу са српским.

4. Српска теолингвистика, како показује овај преглед њених новијих истраживачких преокупација, представља дисциплину у успону која прати тенденције у европској, а посебно словенској науци. Зато је њена перспектива у наредном периоду - кадровско јачање, продубљивање постојећих спознаја, продор на нова подручја испитивања, усавршавање методолошког апарата и праћење актуелних трендова у светским оквирима. Ако овај рад пружи подстрек за њен будући развој, сматраћемо да је постигао свој циљ.

\section{ЛИТЕРАТУРА}

Вуловић 2015: Н. Вуловић, Српска фразеологија и религија, Београд: Институт за српски језик САНУ.

Гадомски 2017: А. К. Гадомский, Теолингвистические исследования в славянских языках, Симферополь: ООО «Форма».

Гадомски/Кончаревић 2012: А. К. Гадомский, К. Кончаревић (ур.), Теолингвистика: међународни тематски зборник радова = Теолингвистика: 
международный тематический сборник статей, Београд: Православни богословски факултет, Институт за теолошка истраживања.

Грковић Мејџор/Кончаревић 2013: Ј. Грковић-Мејџор, К. Кончаревић, Теолингвистичка проучавања словенских језика = Theolinguistic Studies of Slavic Languages, Београд: САНУ - Одељење језика и књижевности.

Кнежевић 2010: И. Кнежевић, Теолошки дискурс енглеског и српског језика. Лексичко-семантички и стилистички проблеми превођења, Београд: Православни богословски факултет, Институт за теолошка истраживања.

Кнежевић 2011: И. Кнежевић, Научни стил енглеског и српског језика у области теологије. Докторска дисертација, Београд: Филолошки факултет (дактилографисани рукопис).

Кнежевић/Ранковић 2014: И. Кнежевић, 3. Ранковић, О лексици радова научно-уџбеничког подстила научног функционалног стила у теологији, Црквене студије, 11, 633-641.

Кнежевић/Ранковић 2016а: И. Кнежевић, 3. Ранковић, О неким аспектима црквеног административног стила, CLIMB. Culture, Language, Literary, Translation, Library and Information Studies, Teaching Methodology and Book History, 4/1, 65-73.

Кнежевић/Ранковић 2016б: И. Кнежевић, 3. Ранковић, Словенски неологизми у академским радовима на српском и енглеском језику у сфери православне теологије, у: А. Прњат (ур.), Language, literature and philosophy = Језик, књижевност и филозофија, Београд: Алфа БК универзитет, Факултет за стране језике, 153-164.

Кончаревић 2013: К. Кончаревић, Сакрална комуникащија: норме, традиuије, средства, Београд: Православни богословски факултет, Институт за теолошка истраживања.

Кончаревић 2015: К. Кончаревић, Поглед у теолингвистику, Београд: Јасен.

Кончаревић 2017: К. Кончаревић, Језик и религија. Појмовник теолингвистике, Београд: Јасен.

Кончаревић/Петровић 2013: К. Кончаревић, С. Петровић, Српска теолингвистика данас: истраживачки проблеми и резултати, Јужнословенски филолог, LXXXII, 1-2, 159-186.

Левушкина 2016: Р. Левушкина, Дескриптивни речник лексема из сфере православне духовности у савременом српском језику, у: С. Ристић. И. Лазић-Коњик (ур.), Лексикологија и лексикографија у светлу савремених nриступа, Београд: Институт за српски језик САНУ, 321-340.

Левушкина 2017a: Р. Левушкина, Лексеме из општег лексичког фонда као термини у сфери православне духовности, у: П. Пипер, В. Јовановић (ур.), Словенска терминологија данас, Београд: Институт за српски језик САНУ, 439-449.

Левушкина 2017б: Р. Левушкина, Термини из сфере православне духовности у савременом српском језику, Јужнословенски филолог, LXXIII, 1-2, $59-82$. 
Левушкина 2019: Р. Левушкина, Русская и сербская православные культуры - сравнительный лексический анализ, у: Е. Е. Белова (ур.), Научная дискуссия: вопросы филологии и методики преподавания иностранных языков, Нижний Новгород: Мининский университет, 67-74.

Левушкина/Јовановић 2018: Р. Левушкина, В. Јовановић, Терминолошки речници на српском језику и у српској лингвистици крајем 20. и почетком 21. века, у: Слов'янське термінознавство кіния XX-початку XXI cmoліть, ур. В. Л. Ивашченко, Київ: Термінологічна комісія при Міжнародному комітеті славістів, 529-543.

Петровић 2015a: С. Петровић, Библиографија расправа и дела из теолингвистике која су изашла у Србији, Црној Гори и Републици Српској од 2000. до 2013. године, у: Б. Шијаковић (ур.), Српска теологија у двадесетом веку: истраживачки проблеми и резултати, Београд: Православни богословски факултет, књ. 18, 116-147.

Петровић 2015б: С. Петровић, О стереотипу вере из угла вербално-асоцијативног система руског и српског језика, Црквене студије, 12, 95-107.

Петровић 2015в: С. Петровић, Стереотип духовности у језичкој свести говорника руског и српског језика (на материјалу асоцијативних речника), Славистика, XIX, 285-295.

Петровић 2016: С. Петровић, О лексици из сфере монашке духовности у руском и српском језику, Славистика, XX, 271-277.

Петровић 2017: С. Петровић, Лексичко-семантичке одлике именица са архисемом „монах” у руском и српском језику, Црквене студије, 14, 609-621.

\author{
К. Й. Кончаревич
}

СЕРБСКИЙ ЯЗЫК В СВЕТЕ ТЕОЛИНГВИСТИЧЕСКИХ ИССЛЕДОВАНИЙ

Резюме

В работе предлагается обзор основных направлений исследований в сербской теолингвистике (в сферах общей лингвистики, сербистики и славистики, а также иностранных филологий), с учетом важнейших результатов, достигнутых в фундаментальных и прикладных аспектах изучения языка сакрума (из синхронической перспективы), которые излагаются в монографических публикациях, трудах, опубликованных в тематических сборниках, сборниках матералов научных конференций и в научных журналах) с 2010 по сегодняшний день.

За минувшее десятилетие сербская теолингвистика вышла из стадии научного становления и теперь находится на этапе усовершенствования. Потенциально располагает широким спектром фундаментальных исследований (в анализируемый период преобладали вопросы конфессиональной маркированности языковых уровней, особенно лексики и фразеологии, функциональной стилистики, стилистики ресурсов, теории дискурса) и практических сфер применения (лексикография, транслятология).

Ключевые слова: теория и методология лингвистики, сербская лингвистика, теолингвистика, сербистика, русистика, славистика, иностранные филологии, монолингвальные и сопоиставительные исследования сербского языка. 